Technical Report

\title{
Urban Household Energy Consumption Structure in China (Part II) - A Provincial Analysis-
}

\author{
Yadong Ning*1, Yutaka TONOOKA*1, Hailin MU*2, Yasuhiko KONDO*2, and Weisheng ZHOU*3 \\ (Received October 26, 2004)
}

\author{
中国都市部家庭部門におけるエネルギー消費構造に関する研究（II） \\ 一地域特徵一 \\ 寧 亜東*1, 外岡 豊*1, 穆 海林*2, 近藤康彦*2, 周 瑋生*3
}

\begin{abstract}
In Part II of this paper, regional (provincial) variations in energy consumption of urban households in China are analyzed using fuel expenditure data from the China Family Income and Expenditure Survey in 1999. A three dimensional matrix data of energy consumption by fuel type (including electricity), thermaluse type, and provinces is estimated using the methodology developed in Part I. In addition, the relationship with the underlying factors that affect the energy consumption structure such as, energy supply conditions, heating or cooling load, and income level are analyzed. The maximum energy consumption per household in 1999 was $36.99 \mathrm{GJ} /$ year 'household in Heilongjiang and the minimum was $8.56 \mathrm{GJ} /$ year .household in Sichuan province. The average for this year was $18.81 \mathrm{GJ} / \mathrm{year} \cdot$ household. The regional variations are due primarily to differences in: space heating load, coal supply conditions and life styles, from variations in levels of income and urbanization.
\end{abstract}

\section{Key Words}

China, Urban, Household, Residential house, Energy consumption, Electricity, City-gas, LPG, Coal

1.はじめに

前報（Part I）1)では, 中国都市部家庭部門エネルギー消費 構造の経年動向（1981年～2000年）について，解析手法を確 立し，20 年間の燃料種類別・熱用途別エネルギー消費構造の 経年動向を詳細に解析した。中国の国土は広く気候条件の違 いや経済発展の不均衡により中国家庭部門のエネルギー消費 実態は地域により多様である。従って, 中国家庭部門エネル ギー消費構造を検討するには，地域ごとのエネルギー消費構 造の多様性を十分考慮した分析が必要と考えられる。また，中 国家庭部門の省エネルギー対策，大気污染防止対策，気候変 動防止対策を検討するには，地域的なエネルギー消費構造の 違いも考慮せざるを得ない。中国地域別都市部家庭部門エネ

* 1 Saitama University

255 Shimo-okubo, Sakura-ku, Saitama-shi, Saitama 338-8570, Japan

* 2 National Institute for Advanced Industrial Science and Technology

16-1 Onogawa, Tsukuba-shi, Ibaraki 305-8569, Japan

* 3 Ritsumeikan University 56-1 Toji-in Kitamachi, Kita-ku, Kyoto 603-8577, Japan
ルギー消費についてはいくつかの研究が行われてきたが，燃 料種類別・熱用途別のエネルギー消費構造を詳細に検討した 研究は少ない。既往の研究事例として例えばBrockett D, et al. ${ }^{2)}$ は数ヶ所の大都市で電力消費について実態調查を行い需要害 態を解析しているが電力だけのミクロな調查事例である。張 ら 3) -8) は中国都市部家庭部門エネルギー消費量を推計し気象 デー夕を用いた地域別暖冷房特性を解析したが，大都市だけ を対象とした解析に止まっている。

本稿では, 中国地域別都市部家庭部門エネルギー消費構造 の特徵を解明するために, 前報 (Part I) で用いた中国都市部 家庭部門エネルギー消費構造の推計方法を地域別推計に適用 して中小都市を含めた地域別都市部家庭部門エネルギー消費

\footnotetext{
* 1 埼玉大学

テ 338-8570 埼玉県さいたま市桜区下大久保 255

* 2 (独)産業技術総合研究所

T 305-8569 茨城県つくば市小野川 16-1

* 3 立命館大学

干 603-8577 京都府京都市北区等持院北町 56-1
} 
構造の特徴についてクロスセクション分析を行う。ここでは 地域とは台湾, 香港, マカオを除く中国の大陸部の省別を指 す。な抢チベット自治区についてはデータがないので除外し た。対象年次は 1999 年である。

\section{2. 推計手法}

\section{1 分析に用いたデータ}

中国都市部家計調査9) では全国平均値の一人当り石炭, LPG，電力の個々の消費量が得られたが，省別にはこれらの消 費量は得られず年間一人当り石炭, LPG, 電力の個々の購 買額9) が得られる。中国価格年鑑 ${ }^{10)}$ の省別都市部石炭, LPG, 電力の価格を与え一人当り石炭, $L P G$, 電力消費量を推計し, 都市部在住人口 ${ }^{11)}$ により省別石炭, LPG，電力の消費量を推 計した。省別の熱供給消費量は中国能源統計年鑑 ${ }^{22}$ の值，都 市ガス消費量は中国経済情報ネットワーク ${ }^{13)}$ の值を用い，都 市部家庭部門における省別・燃料種類別エネルギー消費量を
推計した。これらのデータをTable 1に示す。省別・燃料種類 別エネルギー消費量の推計手順を Fig. 1 に示す。また，1999 年の省別都市部家庭部門エネルギー消費構造推計に用いた主 要なデー夕をTable 2 に示す。

なお，家計調查のデー夕により推計したエネルギー消費量は 実物量であるが, 本研究では低位発熱量に換算してJoule単位 で示す。電力は二次エネルギー $(3596 \mathrm{~kJ} / \mathrm{kWh})$ として分析する。

\section{2 熱用途別エネルギー消費量の推計手順}

本研究では，前報（Part I）で示した中国都市部家庭部門工 ネルギー消費構造の推計方法に基づいて，同様に省別エネル ギー消費構造を推計した。省別都市部家庭部門燃料種類別工 ネルギー消費量の熱用途分解の手順を Fig. 2 に示す。電気機 器別エネルギー消費原単位と省別の各種電気機器の保有率, 床面積, 都市ガス化率及び省別暖冷房デグリーデイのデー夕 に基づいて，省別燃料種類別エネルギー消費量の熱用途別分

Table 1 Annual energy purchasing, prices and consumption of city-gas and heat by province in urban household in China (1999)

\begin{tabular}{|c|c|c|c|c|c|c|c|c|}
\hline \multirow{3}{*}{ Province } & \multicolumn{3}{|c|}{ Annual purchasing } & \multicolumn{3}{|c|}{ Prices } & \multicolumn{2}{|c|}{ Consumption } \\
\hline & Coal & LPG & Electricity & Coal & LPG & Electricity & City-gas & Heat \\
\hline & $\begin{array}{c}\text { RMB/capita } \\
\text { •year }\end{array}$ & $\begin{array}{c}\text { RMB/capita } \\
\text { •year }\end{array}$ & $\begin{array}{c}\text { RMB/capita } \\
\text { •year }\end{array}$ & $\mathrm{RMB} / 100 \mathrm{~kg}$ & $\mathrm{RMB} / \mathrm{kg}$ & $\mathrm{RMB} / 100 \mathrm{kWh}$ & $10^{4} \mathrm{~m}^{3}$ & $\mathrm{PJ}$ \\
\hline Beijing & 25.56 & 23.84 & 125.03 & 18.17 & 1.85 & 36.22 & 150455 & 11.2 \\
\hline Tianjin & 2.45 & 19.32 & 159.07 & 18.17 & 2.50 & 37.90 & 27967 & 30.2 \\
\hline Hebei & 28.11 & 37.09 & 85.59 & 18.00 & 2.00 & 36.80 & 107144 & 20.3 \\
\hline Shanxi & 17.12 & 16.03 & 63.99 & 10.04 & 2.00 & 37.00 & 47466 & 16.0 \\
\hline Inner Mongolia & 29.37 & 15.10 & 70.57 & 10.04 & 2.00 & 31.75 & 7238 & 11.2 \\
\hline Liaoning & 14.70 & 25.85 & 91.79 & 24.69 & 2.40 & 37.00 & 114326 & 38.2 \\
\hline Jilin & 30.62 & 34.37 & 87.54 & 25.00 & 1.90 & 33.90 & 51152 & 16.4 \\
\hline Heilongjiang & 38.52 & 26.63 & 94.16 & 23.45 & 2.00 & 33.90 & 29030 & 20.0 \\
\hline Shanghai & 0.26 & 13.66 & 217.79 & 18.17 & 2.60 & 61.00 & 207056 & 0.2 \\
\hline Jiangsu & 16.04 & 62.88 & 128.18 & 21.00 & 2.40 & 48.82 & 342214 & 0.0 \\
\hline Zhejiang & 4.33 & 75.00 & 167.57 & 25.62 & 2.29 & 53.00 & 25921 & 0.0 \\
\hline Anhui & 28.59 & 43.80 & 98.97 & 21.00 & 3.10 & 45.20 & 27773 & 2.5 \\
\hline Fujian & 9.22 & 81.75 & 169.27 & 23.83 & 3.07 & 36.70 & 3683 & 0.0 \\
\hline Jiangxi & 17.43 & 57.26 & 74.59 & 13.40 & 2.71 & 44.90 & 36464 & 4.0 \\
\hline Shandong & 18.31 & 25.87 & 83.90 & 28.50 & 2.58 & 40.73 & 115664 & 0.0 \\
\hline Henan & 32.83 & 21.18 & 79.07 & 15.00 & 2.46 & 38.25 & 121990 & 5.9 \\
\hline Hubei & 24.46 & 65.20 & 107.00 & 17.00 & 2.33 & 44.57 & 21420 & 0.0 \\
\hline Hunan & 19.53 & 61.81 & 90.60 & 24.00 & 2.00 & 51.10 & 49967 & 1.1 \\
\hline Guangdong & 5.09 & 142.66 & 283.06 & 28.85 & 2.79 & 69.00 & 11245 & 0.0 \\
\hline Guangxi & 3.78 & 106.67 & 127.54 & 18.00 & 3.30 & 43.60 & 2567 & 0.0 \\
\hline Hainan & 0.67 & 110.61 & 92.19 & 27.58 & 3.30 & 55.85 & 216 & 0.0 \\
\hline Chongqing & 1.67 & 1.66 & 140.03 & 21.37 & 4.23 & 36.85 & 41120 & 0.0 \\
\hline Sichuan & 15.24 & 16.32 & 124.38 & 18.87 & 2.67 & 43.50 & 45244 & 0.0 \\
\hline Guizhou & 20.27 & 32.84 & 111.32 & 18.00 & 2.67 & 35.09 & 6306 & 0.0 \\
\hline Yunnan & 5.63 & 37.52 & 100.72 & 24.00 & 2.52 & 37.57 & 13832 & 0.0 \\
\hline Shaanxi & 24.95 & 35.73 & 71.71 & 25.00 & 2.00 & 38.91 & 14156 & 1.4 \\
\hline Gansu & 16.27 & 28.05 & 44.15 & 26.00 & 2.10 & 37.28 & 28422 & 9.9 \\
\hline Qinghai & 26.50 & 39.89 & 51.39 & 18.00 & 1.78 & 27.00 & 24 & 0.9 \\
\hline Ningxia & 17.76 & 28.79 & 65.32 & 20.80 & 1.78 & 35.00 & 3289 & 3.2 \\
\hline Xinjiang & 27.10 & 48.75 & 53.57 & 11.20 & 1.33 & 37.51 & 2450 & 8.6 \\
\hline
\end{tabular}

Source: China Investigation Statistical yearbook on Prices and Urban Household Income and Expenditure 19999), Price Yearbook of China 199910), China Energy Statistical Yearbook ${ }^{12)}$ and China Economic Information Network ${ }^{13)}$ 


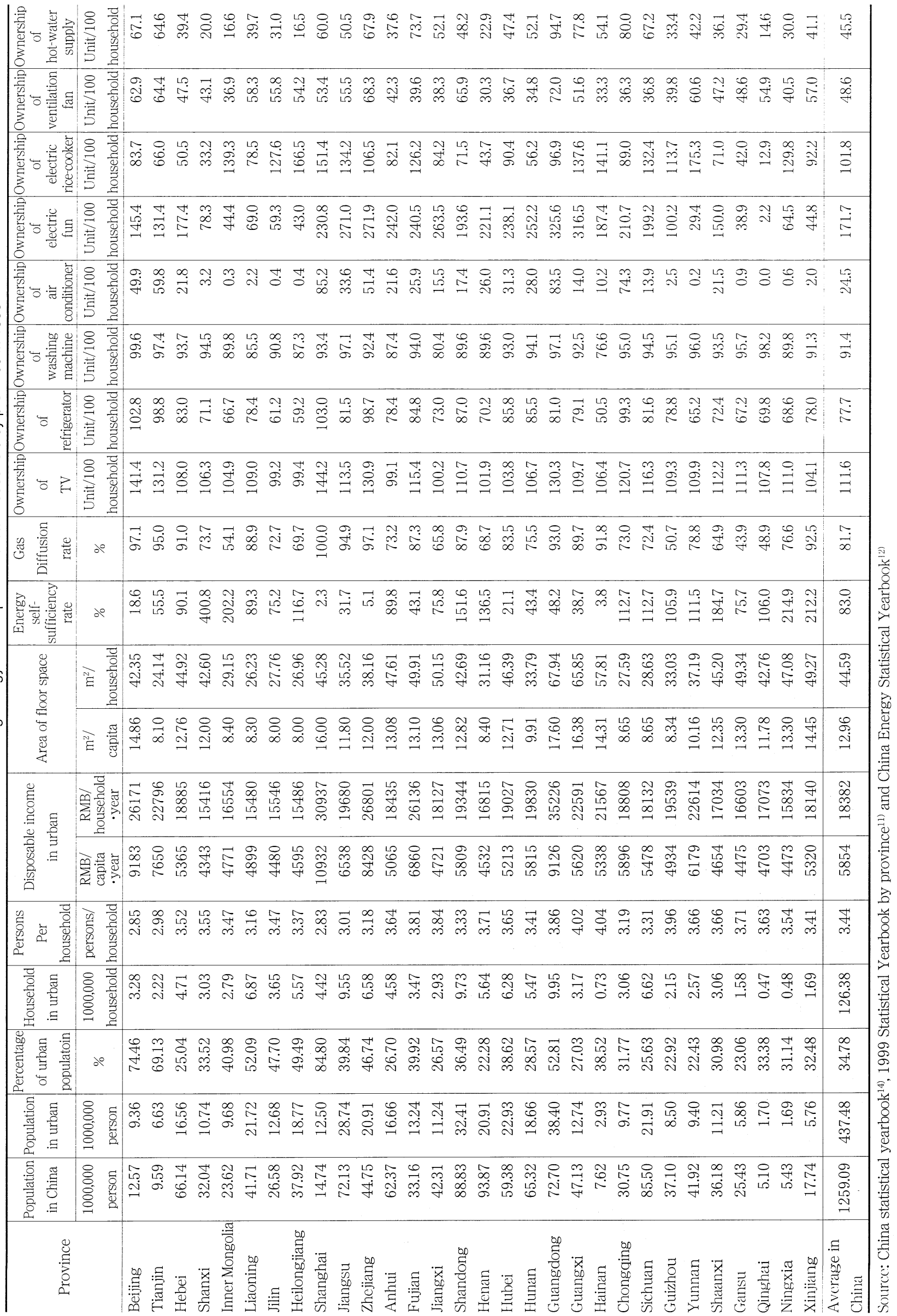




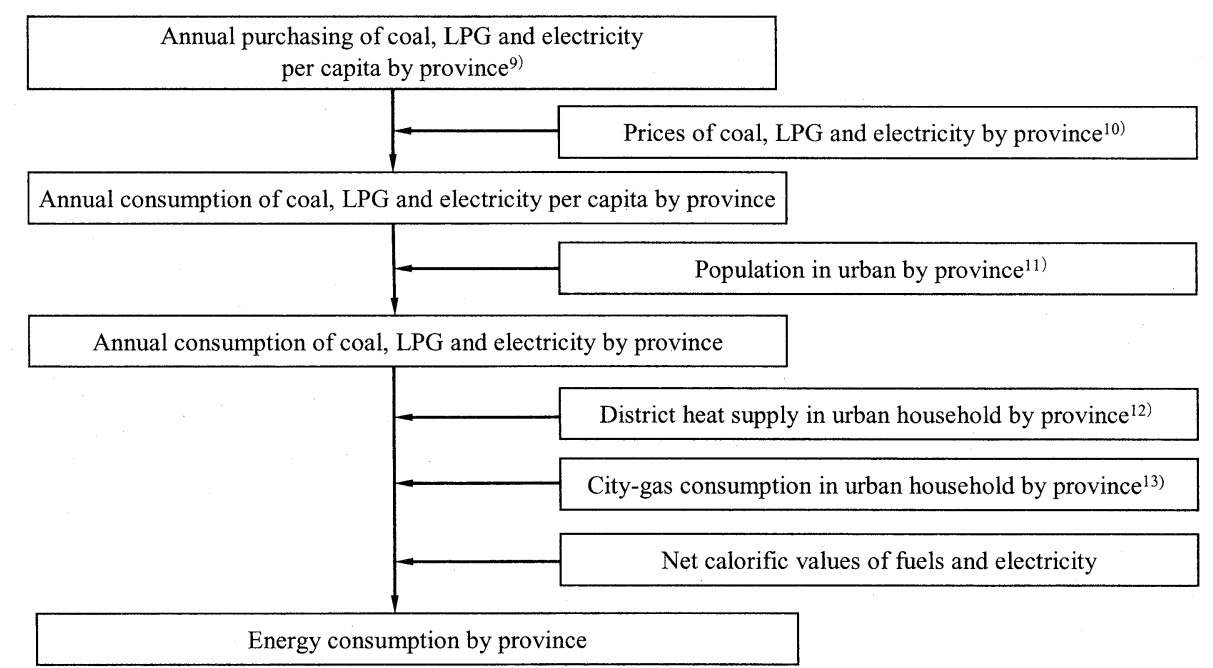

Fig. 1 Estimation procedure of energy consumption in urban household by province

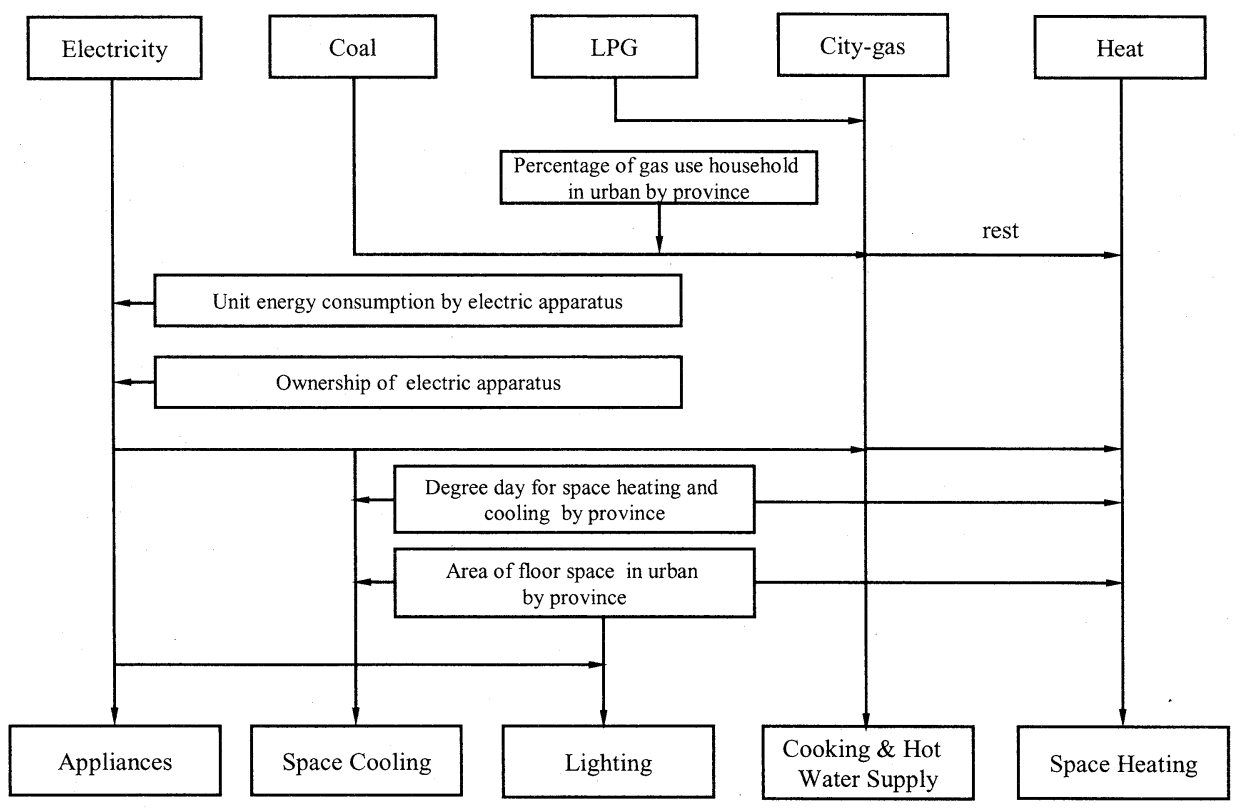

Fig. 2 Estimation procedure of energy consumption by use type in urban household

解を行う。LPG と都市ガスはほとんど厨房・給湯に消費され ている。石炭は暖房と厨房・給湯に消費され, 省別都市ガス 化率と燃料種類別の厨房・給湯エネルギー効率の想定から厨 房・給湯に用いられる石炭消費量の推計を行い, その残りは すべて暖房に消費されるとする。電気機器エネルギー消費原 単位については, 前報 (Part I) で推計した結果を用いる。こ の電気機器別エネルギー消費原単位により, 省別電気機器の 保有率と世帯数, 住宅床面積及び暖房・冷房デグリーデイか ら積み上げ推計した熱用途別電力消費量を仮值とし, Table 1 の家計調查值により推計した省別電力消費量で合計調整した 值を最終值として採用した。家庭部門熱用途別エネルギー消 費量に影響を与える要因のうち, 気候条件は重要な要因であ る。気候の影響を受けやすい熱用途は暖房, 冷房であり, 気 温との相関関係が特に強い。本研究では, 省別の行政府所在 地の月平均気温データ14)を省別都市部全域の代表值として用
い, 暖房デグリーデイ, 冷房デグリーデイを推計した(Table 3に示す)。暖房デグリーデイとは，ある基準の気温を下回る と暖房すると想定した暖房の必要度を示す指標である。ここ

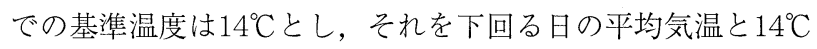
との差を合計したものを用いた $\left(H D D_{14-14}\right)$ 。冷房デグリーデ イについては基準温度を $22^{\circ} \mathrm{C} と し た ~\left(S D D_{22-22}\right)$ 。省別地理位 置を理解するために, 省名入りの中国地図を Fig. 3 に示す。

\section{3 エネルギー消費構造の推計式}

本研究では, 以下に示す式(1)〜 (4)までの推計式を用いて, 省別・燃料種類別・熱用途別エネルギー消費量を算出する。

$$
E_{i}=\sum_{u} E^{u}=\sum_{f} \sum_{u} E_{f}^{u}=\sum_{f} \sum_{a} E_{f}^{a}
$$

ここで, $E_{i}: i$ 省における都市部家庭部門エネルギー消費量。 $i$ : 対象地域の 30 ケ省, $i=1 \sim 30$ 。 
Table 3 Degree day for space heating and cooling by province

\begin{tabular}{|c|c|c|}
\hline Province & Heating degree-day & Cooling degree-day \\
\hline Beijing & 1821 & 384 \\
\hline Tianjin & 1854 & 366 \\
\hline Hebei & 1467 & 450 \\
\hline Shanxi & 2085 & 141 \\
\hline Inner Mongolia & 3063 & 138 \\
\hline Liaoning & 2985 & 189 \\
\hline Jilin & 3708 & 96 \\
\hline Heilongjiang & 4059 & 90 \\
\hline Shanghai & 801 & 363 \\
\hline Jiangsu & 1059 & 345 \\
\hline Zhejiang & 843 & 399 \\
\hline Anhui & 975 & 420 \\
\hline Fujian & 111 & 708 \\
\hline Jiangxi & 609 & 606 \\
\hline Shandong & 1335 & 387 \\
\hline Henan & 1194 & 399 \\
\hline Hubei & 759 & 576 \\
\hline Hunan & 687 & 441 \\
\hline Guangdong & 0 & 945 \\
\hline Guangxi & 51 & 810 \\
\hline Hainan & 0 & 1230 \\
\hline Chongqing & 438 & 525 \\
\hline Sichuan & 660 & 231 \\
\hline Guizhou & 693 & 90 \\
\hline Yunnan & 273 & 90 \\
\hline Shaanxi & 1248 & 342 \\
\hline Gansu & 2043 & 45 \\
\hline Qinghai & 3036 & 0 \\
\hline Ningxia & 2721 & 111 \\
\hline Xinjiang & 3177 & 81 \\
\hline Average in China & 1474 & 355 \\
\hline
\end{tabular}

$E^{u}$ : 熱用途別エネルギー消費量。

$u$ : 熱用途別。 $\mathrm{H}$ ：暖房， C : 厨房 - 給湯， L : 照明, $\mathrm{S}:$ 冷房, P : 動力。

$f$ : 燃料種類別。C : 石炭, L : LPG, G : 都市ガス, $\mathrm{E}$ : 電力, $\mathrm{H}$ : 熱供給。

$E_{f}^{u}:$ 燃料種類別・熱用途別エネルギー消費量。

$a$ : 機器別 (Part I の Fig. 2 を参照)。

$E_{f}^{a}: f$ 燃料を消費する $a$ 機器のエネルギー消費量。

厨房・給湯用世带当り有効エネルギー消費水準は使用燃料 種によらず一律と仮定し，LPG と都市ガスが普及していない 家庭では厨房・給湯用燃料として石炭を使うものと仮定して 省別厨房・給湯用石炭消費量を求めた（式 $(2)) 。$

$$
E_{i, C}^{C}=\left(E_{i . L} \cdot \eta_{L}+E_{i, G} \cdot \eta_{G}\right) \cdot \frac{\left(100-r_{i}\right)}{r_{i} \cdot \eta_{C}}
$$

ここで， $E_{i, C}^{C}$ : i 省における厨房・給湯用石炭消費量。

$E_{i, L}, E_{i, G}: i$ 省における $L P G$, 都市ガス消費量。

$\eta_{L}, \eta_{G}, \eta_{C}$ : 厨房・給湯用 $L P G$ ，都市ガス，石炭の燃焼効

率。それぞれ $50.0 \% ， 50.0 \% ， 22.1 \%$ とした ${ }^{15}$ 。 $r_{i}: i$ 省に打ける都市ガス化率，\%。

また，暖房，冷房は気候の影響を受けやすいため，省別暖 房，冷房エネルギー消費構造の分析には，気候要因を考慮し 下記の式で推計される。対象機器はエアコンと扇風機である。

$E_{i}^{H}=e_{A}^{H} \cdot n_{i, A} \cdot m_{i} \cdot \mathrm{S}_{i} \cdot H D D_{i} / H D D_{C}$

$E_{i}^{\varsigma}=\left(e_{A}^{S} \cdot n_{i, A}+e_{F}^{S} \cdot n_{i, F}\right) \cdot m_{i} \cdot S_{i} \cdot S D D_{i} / S D D_{C}$

ここで, $E_{i}^{H}, E_{i}^{S}: i$ 省における暖房, 冷房の電力消費量。

$e_{A}^{H}, e_{A}^{S}, e_{F}^{S}$ : エアコン (暖房用), エアコン (冷房用), 扇 風機のエネルギー消費原単位 (Part Iの Table 3 の床面積当り原単位を用いる)。

$n_{i, A}, n_{i, F}: i$ 省におけるエアコン, 扇風機の保有率, 台/ 百世带。

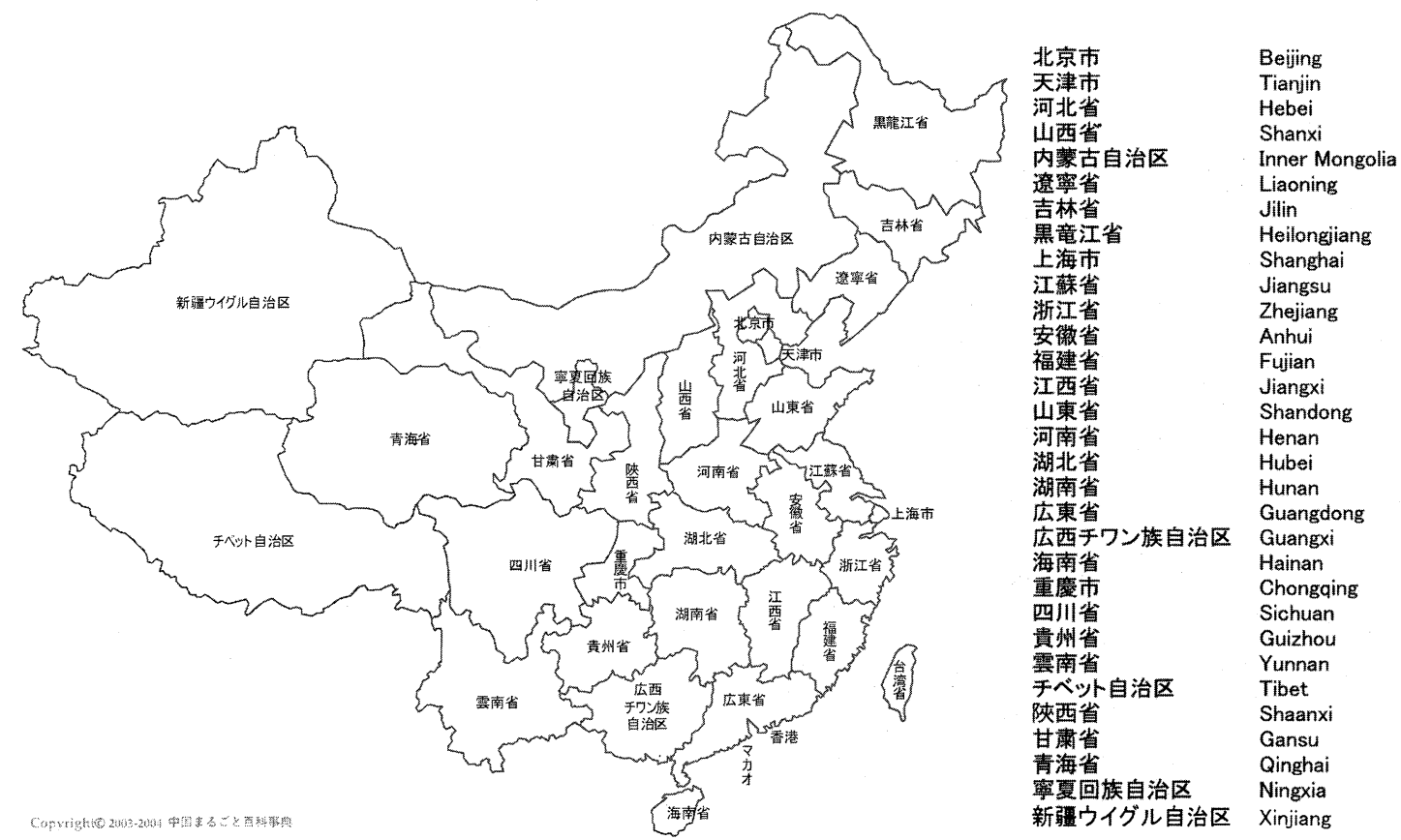

Fig. 3 Chinese map by province 
$m_{i}, S_{i}$ : $i$ 省における都市部世帯数, 世帯当り床面積。 $H D D_{i}, H D D_{C}$ : それぞれ $i$ 省と中国全域 (平均) の暖房デグ リーデイ。

$S D D_{i}, S D D_{C}$ ：それぞれ $i$ 省と中国全域（平均）の冷房デグ リーデイ。

\section{3. 推計結果及び考察}

\section{1 省別燃料種類別エネルギー消費量}

式(1)により推計した 1999 年における中国都市部家庭部門 エネルギー消費量は 2392PJである。経年全国推計值 2238PJ (Part I の推計結果) に比べて $7 \%$ 大きいが, 地域別特徵の比 較が目的なので，全国值に調整しないで，このまま分析する。 また，中国能源統計年鑑12)の省別エネルギーバランス表より 推計した結果は2003PJで, 石炭, LPG, 電力について省別家 計調査による本推計より $14 \%$ むさい。

省別燃料種類別エネルギー消費量を Fig. 4 に示す。最大の 消費量は黒龍江省 (Heilongjiang) で205.98PJ，全国の 8.6\%を 占めるが, それに次いでいるのは広東省 (Guangdong), 遼寧 省 (Liaoning), 河南省 (Henan), 江蘇省 (Jiangsu), 吉林省 (Jilin), 湖北省 (Hubei), 河北省 (Hebei), 北京市 (Beijing), 山 東省 (Shandong)であり，いずれも100PJを超える。その他の 省の多くは50PJ前後であり, 最も少ないのは青海省 (Qinghai) の 9.28PJである。燃料種類構成は地域によりかなり異なって いる。産炭地域である黒龍江省, 吉林省, 遼寧省, 内蒙古自 治区 (Inner Mongolia), 山西省 (Shanxi), 陝西省 (Shaanxi), 安 徽省 (Anhui) などはいずれも石炭の消費量が多い。一方, 北 京市, 天津市(Tianjin), 上海市 (Shanghai), 広東省, 江蘇省, 浙江省 (Zhejiang), 福建省 (Fujian)などの急成長を遂げた東部 沿岸部発展地域ではエネルギー自給率が低く（Table 2 を参 照), 石炭の消費量が少なく, LPGと都市ガスの消費量が多い。 算出された省別のエネルギー消費量を都市部在住人口，世帯 数と床面積で除し, 1999年の省別一人当り, 世帯当り, 床面 積当り燃料種類別エネルギー消費量を求めた。省別世帯当り 燃料種類別エネルギー消費量を Fig. 5 に示す。全般的に寒冷 地域では石炭の消費量が多く, 黒龍江省, 吉林省, 内蒙古自 治区では石炭はエネルギー消費量の $60 \%$ 以上を占めている。 逆に温暖地域の広東省, 上海市, 浙江省, 海南省 (Hainan)で は石炭の消費量は少なく, LPGと都市ガスの消費量が多い。ま た, 北京市, 天津市, 上海市, 重慶市 (Chongqing) の大都市

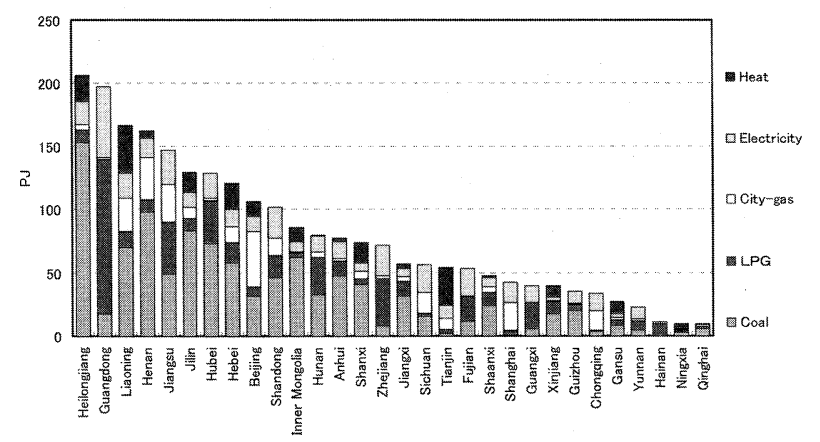

Fig. 4 Composition of energy consumption by province in 1999

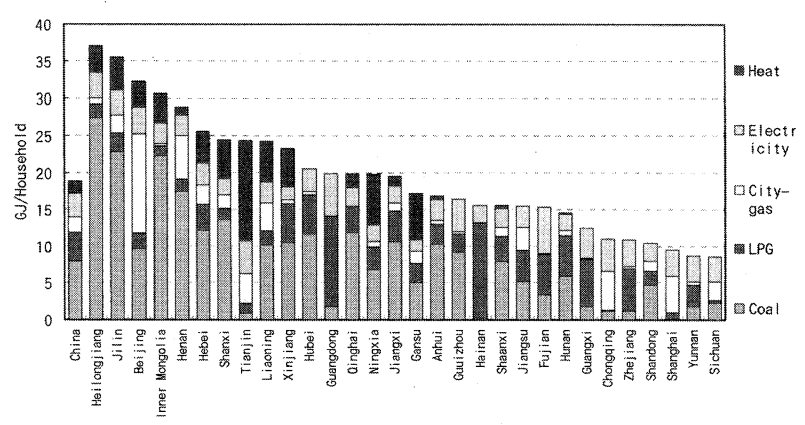

Fig. 5 Energy consumption per household by province in 1999

圏では経済発展と都市化の進行により利便性の高いLPG，都 市ガスと電力の消費量が多いと見られる。世帯当り消費量の 最大は黒龍江省の 36.99GJ/世帯, 最小は四川省 (Sichuan) の $8.56 \mathrm{GJ} /$ 世帯, 平均は $18.81 \mathrm{GJ} /$ 世帯である。世帯当りの格差は 4.3 倍となっている。一人当りエネルギー消費量の最大は北京 市の $11.29 \mathrm{GJ} /$ 人, 最小は雲南省 (Yunnan) の $2.38 \mathrm{GJ} /$ 人, 平均 は $5.47 \mathrm{GJ} /$ 人である。一人当りの格差は4.8倍となっている。Fig. 5によると, 中国都市部地域別家庭部門エネルギー消費構造の 燃料構成は多様であることが分かる。この多様性は経済的，気 候的及び供給条件など様々な要因に決定されていると考えら れる。

\section{2 省別熱用途別エネルギー消費量}

省別世帯当り熱用途別エネルギー消費量を Fig. 6 に示す。 省別世帯当りエネルギー消費量の地域差の主因は気候の違い であり暖房用エネルギー消費量に大きな差がある。また次い で毞房・給湯用の寄与が大きく，その地域差も影響が大きい。 照明, 家電機器, 冷房の電力消費の寄与は小さい。中国農村 部では電力消費量はさらに低いが都市部においても家電機器 の電力消費の割合が低いことは中国家庭用エネルギー消費の 特徴である。広東省だけが例外的に冷房用電力消費が大きい が, 先進大都市, 温暖地域においても各省ともに冷房用工ネ ルギー消費の寄与は小さい。以下熱用途別に実績消費量と有 効エネルギー消費量について各論する。

\section{3 省別暖房用エネルギー消費原単位}

中国北部の寒冷地域では暖房用世帯当りエネルギー消費量

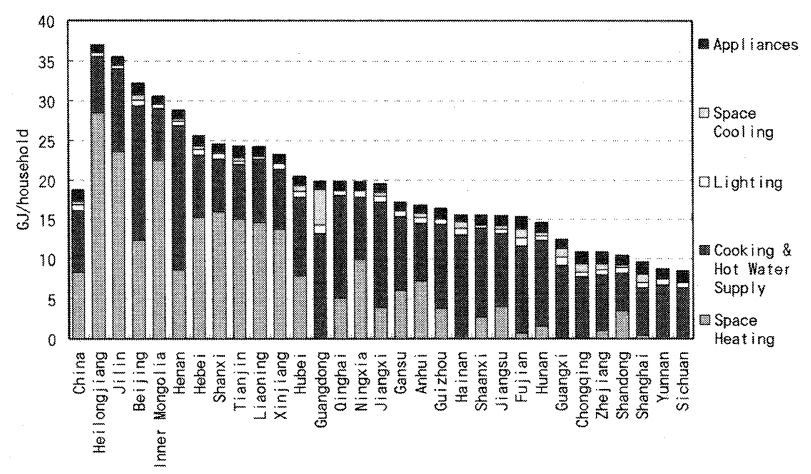

Fig. 6 Energy consumption per household by province and use type in 1999 
が多く，黒龍江省の $28.49 \mathrm{GJ} /$ 世帯が最大である。それに次い でいるのは吉林省，内蒙古自治区，山西省，河北省，天津市 であり，いずれも15GJ/世带を超える。一方，南部の温暖地域 では暖房用エネルギー消費量がほとんどない省もある。冷房 用エネルギーは暖房に比べて小さく，広東省 (4.43GJ/世帯, 20 \%）以外は現状では寄与は小さい。一人当りでは黒龍江省は $8.45 \mathrm{GJ} /$ 人で平均の 3.5 倍，寒冷地域では $4 \mathrm{GJ} /$ 人以上のところ が多く，北京市，天津市も $4 \mathrm{GJ} /$ 人以上ある。床面積当りでは 最高が黑龍江省の $1.06 \mathrm{GJ} / \mathrm{m}^{2}$ で平均の 5.66 倍である。暖房負 荷が大きい東北地方や内蒙古では住居規模は小さい傾向があ り床面積当り暖房エネルギー消費量が相対的に大きくなって いる。天津市では熱供給量が大きく石炭消費が小さい割に暖 房エネルギー消費量が大きくなっている。このことから今後 東北地方等の寒冷地域で一人当り都市部床面積が増大すると, それに連れて暖房用エネルギー消費が増大する恐れがある。 熱効率向上が熱源のガス化等燃料の転換を契機として実現で きればその増大を和らげることが可能になる。本研究では，中 国都市部の地域暖房と分散暖房（石炭）の熱効率をそれぞれ $64 \%$ と $56 \%$ と想定 ${ }^{15}$ して省別暖房用世帯当り，一人当り，床 面積当り有効エネルギー消費量を推計した。省別暖房用一人 当り有効エネルギー消費量を Fig. 7 に示す。また，省別一人 当り暖房用有効エネルギー消費量と暖房デグリーデイの相関 関係を Fig. 8 に示す。強い正の相関関係があり，決定係数は

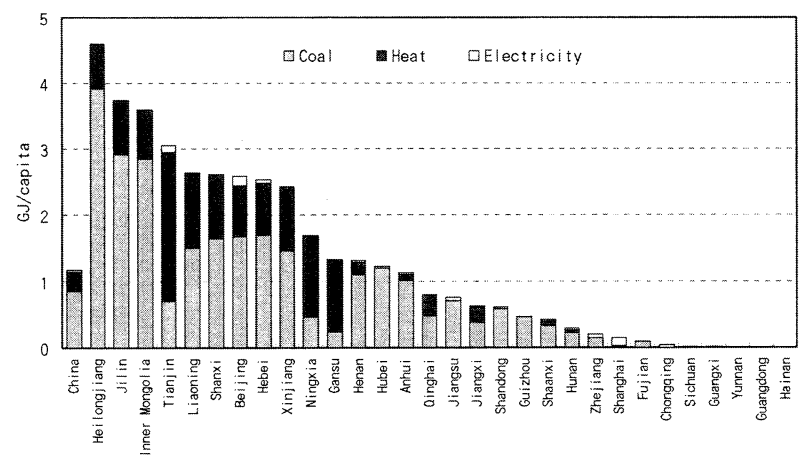

Fig. 7 Effective energy consumption for space heating per capita by province in 1999

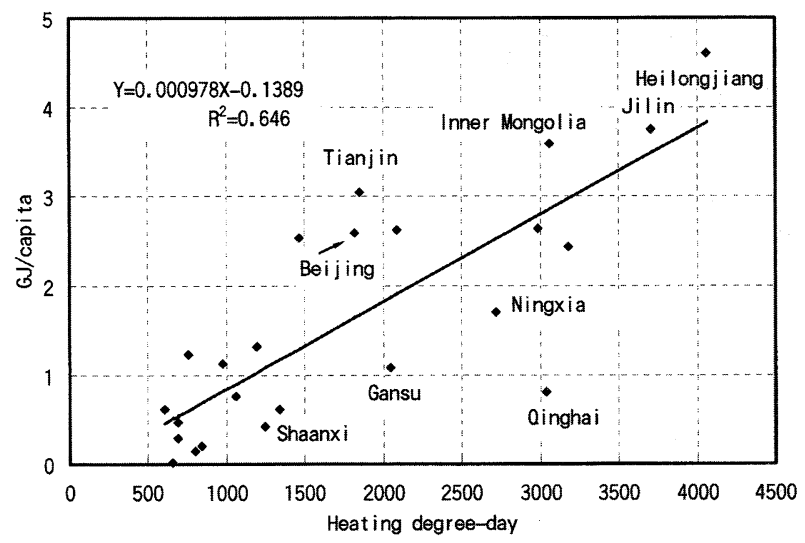

Fig. 8 Relationship between heating degree day and effective energy consumption of space heating per capita by province in 1999
0.65 となった。青海省の暖房用有効エネルギー消費量は例外 的に低いと見られるが，未開発地域であるため，家庭部門の エネルギーは厨房・給湯に優先して消費されると考えられる。 寧夏回族自治区 (Ningxia), 甘肃省 (Gansu), 陝西省において も暖房デグリーデイに比べて暖房用有効エネルギー消費量が 低い傾向がある。これらの省では暖房が不十分で室温が低い 可能性がある。

北京市，天津市では暖房デグリーデイに比べて暖房用有効 エネルギー消費量が大きいが都市化に伴う要求水準の上昇 (すなわち暖房室温が十分高い)を反映していると考えられる。

\section{4 省別厨房・給湯用エネルギー消費原単位}

省別一人当り厨房・給湯用エネルギー消費量を Fig. 9 に示 す。厨房・給湯用エネルギー消費量は地域により差がある。一 人当り懕房・給湯用エネルギー消費量の最大は北京市の 5.97 $\mathrm{GJ} /$ 人, 最小は山東省の $1.3 \overline{\mathrm{GJ}} /$ / 人である。その格差は4 4.4 倍と なっている。省別一人当り厨房・給湯用有効エネルギー消費 量をFig. 10 に示す。一人当り厨房・給湯用有効エネルギー消 費量の最大は北京市の $2.94 \mathrm{GJ} /$ 人である。それに次いでいるの は貴州省，広東省，河南省であり，いずれも $1.5 \mathrm{GJ} /$ 人を越え る。寧夏回族自治区以下 7 地域では $0.7 \mathrm{GJ} /$ 人程度と低い。最 小は内蒙古自治区の $0.49 \mathrm{GJ} /$ 人である。その他の多くの省では $1.0 \mathrm{GJ} /$ 人前後である。

\section{5 省別電力消費量の熱用途別構成}

省別一人当り熱用途別電力消費量を Fig. 11 に示す。福建 省，天津市，広東省，重慶市，上海市，北京市の一人当り電

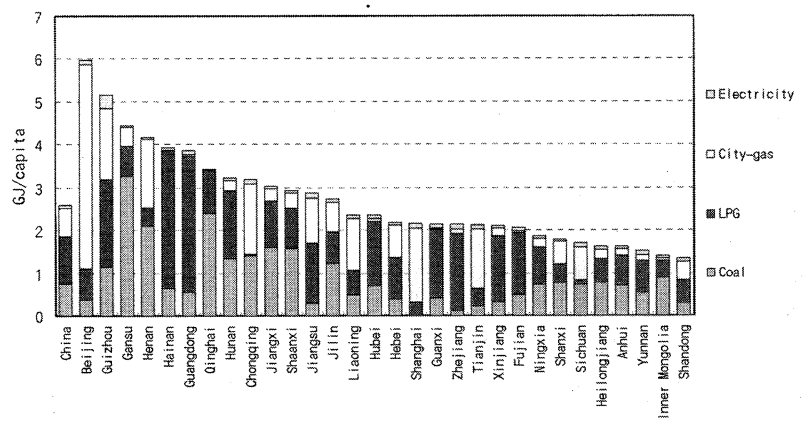

Fig. 9 Energy consumption of cooking and hot water supply per capita by province in 1999

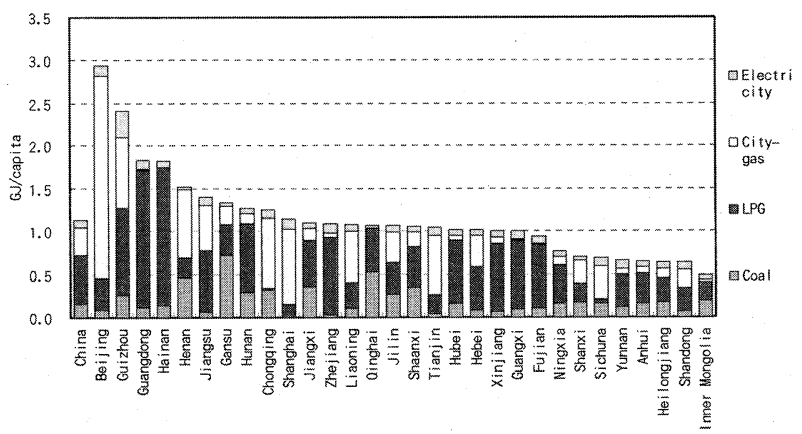

Fig. 10 Effective energy consumption of cooking and hot water supply per capita by province in 1999 
力消費量が高い。地域格差を用途別に見ると家電機器と冷房 用の電力消費がともに多い地域で一人当り電力消費量が高い。 冷房電力消費が大きい地域は冷房負荷とエアコン保有率が共 に高いためである。省別一人当り可処分所得と一人当り電力 消費量との相関関係を Fig. 12 に示す。経年動向分析 (Part I) と同様に電力消費量は生活水準と正の相関関係があり, 生活 水準の向上は電力消費量増加の重要な要因であると考えられ る。しかし, 省別相関の決定係数は 0.46 であり, 経年動向の 決定係数の 0.98 よりかり低い。その理由として, 経済的な 要因以外に気候条件も重要な要因であると考えられ, Fig. 11 に見るように冷房の電力消費量は地域によりかなりの差が見 られる。

エアコン, 家電機器ともに今後の所得増大に伴い急速に普 及が進むものと予想され現状での電力需要水準が低いだけに 伸びの余地も大きく，この分析では1999年当時のデー夕であ るが，最新現況では電力需要がすでに大幅に伸びている。 2002年北京市，上海市と広東省の家庭部門電力消費量は1999 年の $1.87 ， 1.33 ， 1.31$ 倍となっている。2003年以来の中国31ヶ 省市の内，20ケ省市以上に拈いて広域の停電或いは電力使用 制限の状況は家庭部門の電力消費の増加が一つの要因である と考えられており, 特に発展地域の北京市, 上海市, 広東省 の電力供給不足がもっとも深刻な状況にある。

Brockett D, et al. ${ }^{2)}$ は北京市，上海市についてたまたま同じ 1999年に電力消費実態調査を行っている。これは各都市50世 带だけの抽出調査であるが，北京市は4.9GJ/世带·年，上海市

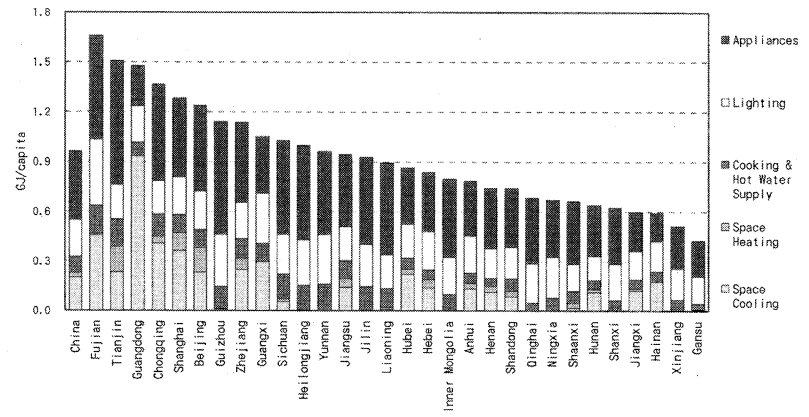

Fig. 11 Electricity consumption for use type per capita by province in 1999

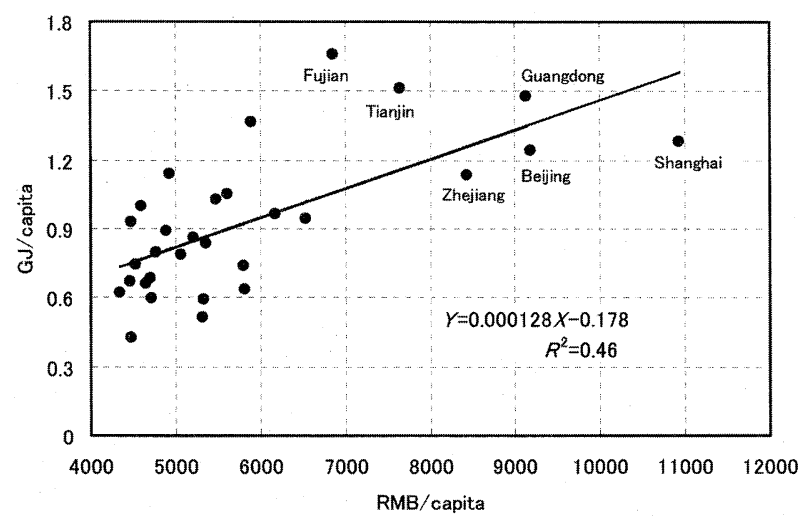

Fig. 12 Relationship between disposal income per capita and electricity consumption per capita by province
は $5.8 \mathrm{GJ} /$ 世帯·年で本推計のそれぞれ 1.4 倍，1.6倍である。こ の違いは本推計が行政区域全体の平均であるのに対し抽出調 査は市内の中心部に近い住宅地域の高所得者層が対象になっ ているためと考えられ, 妥当な差であろう。本推計で代表さ れる行政区域平均值の背景にはこのような大きな巾をもった 個別事例が存在しているということがこの比較から確認理解 される。

\section{6 省別エネルギー消費マトリックス}

Figs. 13〜18は各地域の特徵を代表する省の都市部家庭部 門エネルギー消費マトリックスである。黒龍江省は暖房負荷 が高い東北地域, 山西省は華北地域, 上海市は発達先進地域 である華東地域, 広東省は冷房負荷が高い華中地域, そして 西南地域の貴州省および西北地域の陝西省は経済未開発地域 の代表である。同時に, 上海市と広東省は東部沿岸部経済発

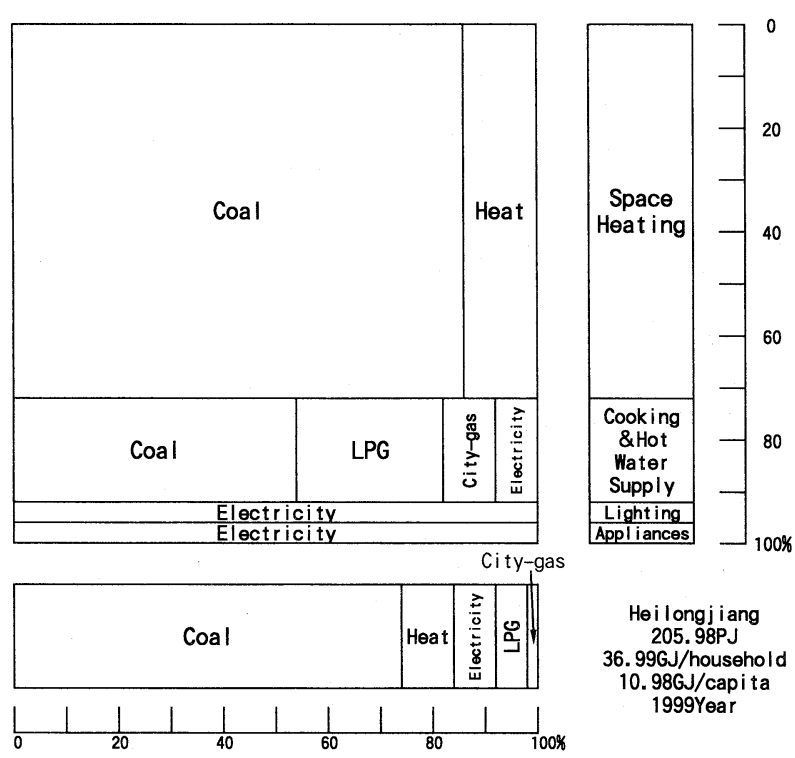

Fig. 13 Matrix of energy consumption in Heilongjiang in 1999

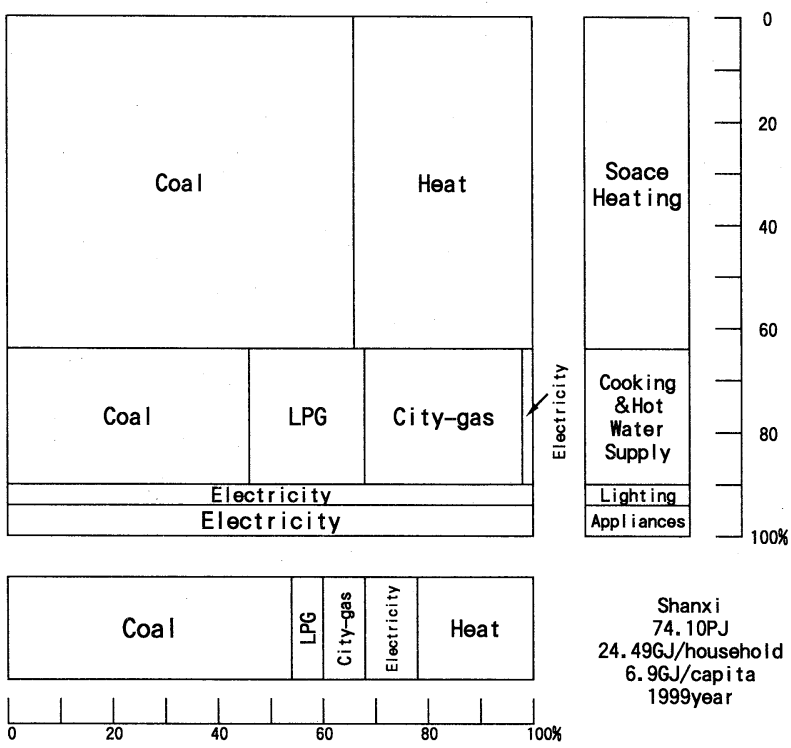

Fig. 14 Matrix of energy consumption in Shanxi in 1999 

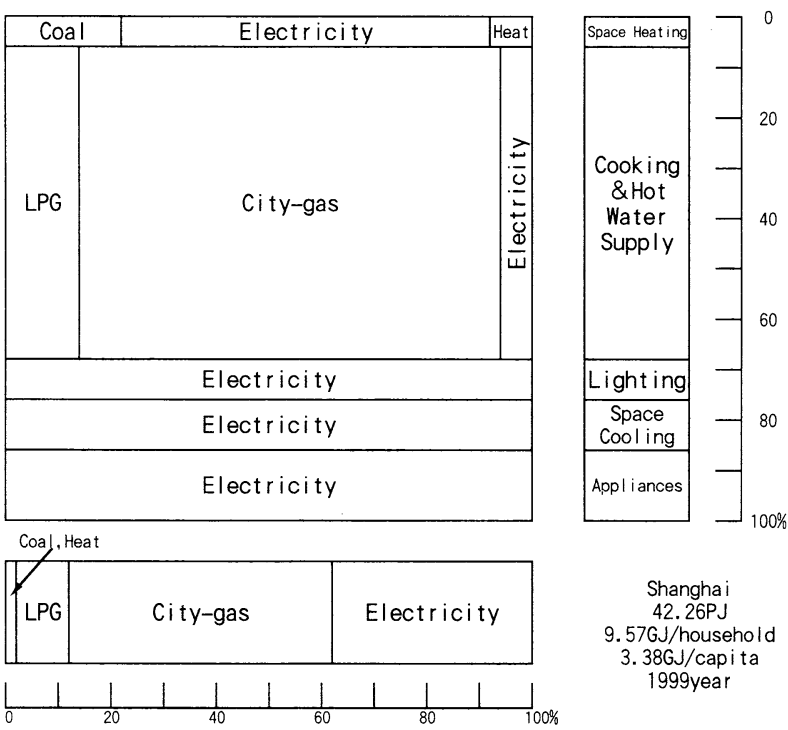

Fig. 15 Matrix of energy consumption in Shanghai in 1999
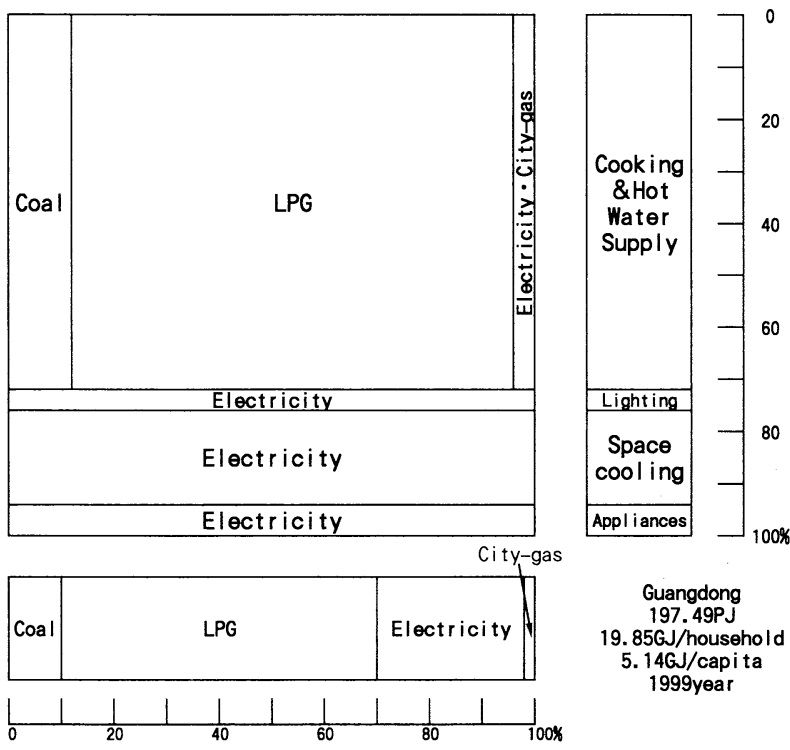

Fig. 16 Matrix of energy consumption in Guangdong in 1999

展地域に, 黒龍江省, 山西省は中部地域に, 貴州省と陝西省 は経済末開発な西部地域にそれぞれ属している。寒冷地域に 位置し産炭地域でもある黒龍江省と山西省では石炭依存度が 高く且つ暖房熱需要が大きい。石炭はエネルギー消費量の50 $\%$ 以上，暖房はエネルギー消費量の $60 \%$ 以上を占めている。 また，地域暖房の普及率が高いため，熱供給量の割合が高い。 一方，エネルギー自給率が低く経済発展地域である上海市と 広東省では石炭の依存度が非常に低く, 広東省ではエネル ギー消費量の $10 \%$ ，上海市ではエネルギー消費量の $1 \%$ 未満 である。上海市と広東省の電力消費量の割合はほかの地域よ り高く, エネルギー消費量の $30 \%$ 以上を占めている。広東省 では暖房用エネルギー消費量はほとんどなく, 冷房用エネル ギー消費量の割合はエネルギー消費量の約 $20 \%$ を占めている。 これらの経済発展地域では都市化の進行とライフスタイルの 変化により, 利便性の高いエネルギーへの転換が進んでいる。

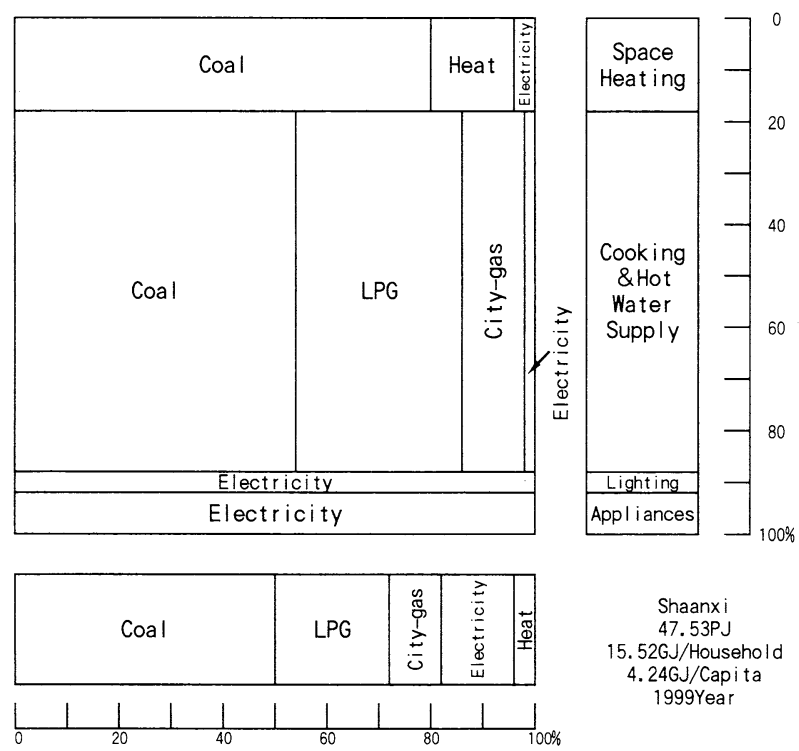

Fig. 17 Matrix of energy consumption in Shaanxi in 1999

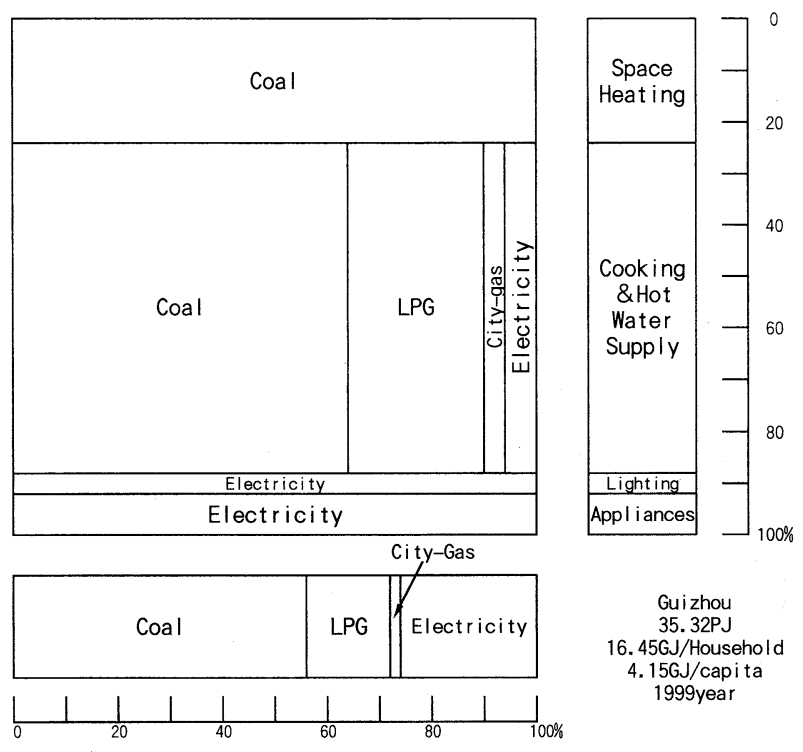

Fig. 18 Matrix of energy consumption in Guizhou in 1999

西部地域の貴州省と陝西省では一人当りエネルギー消費量が 低く，厨房・給湯用エネルギー消費量の割合が高い。経済未 開発な地域であるため，家庭部門のエネルギー消費量は厨房. 給湯用に優先消費されていると考えられる。また，石炭の依 存度が高く，特に懕房・給湯用石炭消費量の割合が高い。こ れらの地域のエネルギー消費が現状で低水準であることは, 今後経済発展地域に類似したエネルギー消費構造に移行して ゆくことにより，今後の中国のエネルギー消費量がさらに増 大する潜在的要因となっていると考えられる。

\section{4. 終わりに}

本研究では，前報 (Part I) と同様の方法で1999年における 都市部家庭部門燃料種類別熱用途別エネルギー消費量を省別 に推計し，エネルギー消費構造の特徴について分析した。分 析結果をまとめると以下のようになる。 
（1）家計調査デー夕を基礎資料として用いることにより中国省 別都市部家庭部門エネルギー構造のより正確詳細な解析が 可能になった。

(2) エネルギー自給率の高い産炭地域の省では家庭部門の石炭 消費量が多い(例：黑龍江省，山西省）。

（3）エネルギー自給率の低い省では石炭消費量が少なく, LPG と都市ガス消費量が多い（例：広東省，浙江省）。

（4）大都市圏では生活水準とライフスタイルを反映して都市ガ スと電力の消費量が多い(例：北京市, 天津市, 上海市)。

（5）省別世帯当り，一人当りエネルギー消費量の格差は $4.3 ， 4.8$ 倍となっている。この地域差の主因は気候の違いであり暖 房用エネルギー消費量に大きな差がある。

(6) 省別暖房用有効エネルギー消費原単位は省別暖房デグリー デイと強い正の相関関係がある。

（7）省別電力消費原単位, 都市ガス消費原単位は省別の生活水 準と正の相関関係がある。

\section{文 献：References}

1）寧亜東, 外岡豊, 穆海林, 近藤康彦, 周瑋生, 日本エネル ギー学会誌, 85(5), 371-380 (2006) :Ning Y. D., Tonooka Y., Mu H. L., Kondo Y., Zhou W. S., J. Jpn. Inst. Energy, 85 (5), 371-380 (2006)

2) Brockett, D., David F., Lin J. M., Lin J., ACEEE Summer Study on Building Energy Efficiency, (Lawrence Berkeley National Laboratory), p. 8.29-8.40 (2002)

3）張晴原, 浅野賢二, 日本建築学会計画系論文集, 543, p. 6569 (2001) :Zhang Q. Y., Asano K., J. Archit. Plann. Environ. Eng., AIJ, 543, p. 65-69(2001)
4）張晴原, 浅野賢二他, 日本建築学会計画系論文集，548, p. 69-74(2001) :Zhang Q. Y., Asano K., et al., J.A rchit. Plann. Environ. Eng., AIJ, 548, p. 69-74(2001)

5）張晴原, 浅野賢二他, 日本建築学会計画系論文集, 555, p. 61-68 (2002) :Zhang Q. Y., Asano K., et al., J. Archit. Plann. Environ. Eng., AIJ, 555, p. 61-68 (2002)

6）張晴原, 浅野賢二他, 日本建築学会計画系論文集, 555, p. 69-76 (2002) :Zhang Q. Y., Asano K., et al., J. Archit. Plann. Environ. Eng., AIJ, 555, p. 69-76(2002)

7）張晴原，浅野賢二，日本建築学会計画系論文集，565, p. 5560 (2002) :Zhang Q. Y., Asano K., J. Archit. Plann. Environ. Eng., AIJ, 565, p. 55-60 (2002)

8) Zhang Q. Y., Energy and Buildings, 36, p. 1217-1225 (2004)

9) China Investigation Statistical Yearbook on Prices and Urban Household Income and Expenditure 1999, (China Statistics Press), (2000)

10) Price Yearbook of China1999, (China Price Press), (2000)

11) 1999 Statistical Yearbook by province, (China Statistics Press), (2000)

12) China Energy Statistical Yearbook 1997-1999, (China Statistics Press), (2001)

13) China Economic Information Netwrok, http://www.cei. gov.cn/

14) China Statistical Yearbook 1999, (China Statistics Press), (2000)

15) Hu X. L., Jiang K. J., et al., Evaluation of Technology and Countermeasure for Greenhouse Gas Mitigation in China, (China Environmental Science Press), p. 176-225 (2001) 